\title{
The Filipino learner: A socioemotional perspective
}

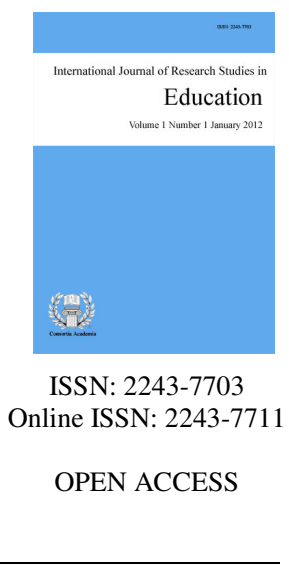

Rungduin, Teresita T.

College of Graduate Studies and Teacher Education Research, Philippine Normal University, Philippines (rungduin.tt@pnu.edu.ph)

Reyes, Zenaida Q.

College of Graduate Studies and Teacher Education Research, Philippine Normal University, Philippines (reyes.zq@pnu.edu.ph)

Accepted: 2 November 2015

\begin{abstract}
The study explored attributes of Filipino learners from the lens of social and emotional development to provide up-to-date data on developmental tasks of Filipino children from kinder to Grade 10. Learners' attributes and developmental characteristics are important data in drawing program standards and learning area competencies in educational practice. Using the case study method with research techniques such as interview of students, teachers and parents, observation and survey of teachers, results reveal that Filipino learners can be at par with the characteristics and developmental tasks presented by educational theorist. However, there are distinct Filipino socio-emotional attributes which can become the bases of learning standards for Filipinos. A number of tasks of Filipino learners are shown within the context of Filipino culture and realities. Since this research is exploratory, new areas of study have emerged. Social and emotional components may be studied through language, stories and everyday life situations of children. Studies comparing the developmental characteristics of children and the competencies of various learning areas in the K-12 curriculum may also be investigated.
\end{abstract}

Keywords: social; emotional; development; tasks; values 


\section{The Filipino learner: A socioemotional perspective}

\section{Introduction}

In the past, studies on the Filipino learners focused on nutrition and intellectual performance (Guthrie, Guthrie, \& Tayag, 1968), school achievement, self-concept and self-esteem, language and effects of sociocultural, school and home environments (Ventura, 1994). There were also studies done about the characteristics of Filipino learners by grade level. These researches dealt with understanding the Filipino learners and served as platforms for students' research interests, development of instructional strategies, curricular designs and understanding the Filipino children. However, the studies seemed to be static, fragmented and unable to provide a whole picture of who the Filipino learners are. Moreover, these researches have been limited in as far as publication and dissemination to stakeholders were concerned.

In 1994, a report (Ventura, 1994) was published on the review of current literature on the Filipino learners from 1971 to 1994 with the primary question of "What do we know of the Filipino Child as a learner?" The study produced a number of issues and recommendations, among these are: (1) Studies on school achievement are the most directly related to the psychology of the child as a learner. In the studies reviewed, achievement has been related to parenting styles and its antecedents and causal attributions have been explored. However, dynamic approaches as to studying the cognitive processes were not explored from among the researches. (2) Studies on self-concept and self-esteem provide some data which can generate one or two generalizations, but the related and seemingly more important variable - that of self-control is absent from the literature. This is important so that schools will be able to find out how to teach children how to plan, create and make decisions which deserve a lifetime commitment. (3) Studies on language development point to differentials in cognitive performance as a function of language used. This emphasizes the need for more systematic studies in this area as input for formulating policy on the language of instruction.

Likewise, parenting styles were studied in the context of academic achievement, however, areas where the environment of learning (including the teacher) was not studied. Studies on perception could likewise be systematized to serve as inputs for planning a conducive environment for learning and presenting materials for the child. Ventura (1994) further elaborated that an area of research deserving more attention is creativity. The creative process should serve as inputs for planning a conducive environment for learning and presenting materials for the child. Moreover, the creative process should be studied especially in terms of scientific and artistic creativity. Lastly, while Piaget's theory continues to attract researchers, it must be stated that there is a need to explore other theories of cognition. There is a need to take the Filipino Child's responses within the context of his or her own culture and cease to use Western standards in asserting the existence of "lags." From the work of Ventura (1994), there had been no significant efforts in updating the existing literature on learner development in a wider perspective covering the areas mentioned above. To further provide information to the extant data with the aim of integrating gathered knowledge to provide educators with areas to improve teaching and learning. Hence, this research intends to explore the nature and characteristics of the Filipino learners.

\subsection{Conceptual framework}

The children's social development was linked to Erik Erikson's psychosocial stages concentrating on the indicators per stage and the virtues accompanying each stage. The areas of focus were from the second stage (4-6 years old) until the fourth stage (13-20 years old). The second stage, development of initiative versus guilt (ages 4 to 6 years old) is characterize by the development of what children think they could do to have a place in the family and explore where they can be good at. The third stage (7 to 12 years old), also called Industry versus Inferiority is the stage where children work on what they could do best as a result of the initiative stage. The development of feelings wanting to be competent in their chosen interests, friends, roles and tasks are 
emphasized. The stage promotes the development of the virtue of competence characterized by becoming capable of performing increasingly complex tasks. As a result, they strive to master new skills. Children who are encouraged and commended by parents and teachers develop a feeling of competence and belief in their skills. Whereas, those who were not, feel inferior compared to what their peers can accomplish. The fourth stage is entry to adolescence, Identity versus Role Confusion extending from 13 to 20 years old. The period covered by research is in the early adolescence part $(13-16)$ which is characterized by the formation of identity leading to defining their roles not only within the family but in the society. The accompanying virtue is fidelity centering on being true and fortifying the identity constructed.

The emotional development component of the study is anchored on the Sroufe's (2000) organizational approach. This approach is based on systems theory- emphasizes the role of emotions as regulators and determinants of both intrapersonal and interpersonal behaviors, as well as stressing the adaptive role of emotions. Sroufe (2000) emphasized in the model what emotions develop, how, when and why. He further classified issues in emotional development by age levels, the ones covered in the study would be those between 30 to 54 months where issues center on management of impulses, sex role identification and peer relations with the roles of the caregivers being a provider of clear roles and values and a model of flexible self-control. The research also covers issues of those between 6 to 11 years old, and centers on the consolidation of self-concept, formation of loyal friendships, ensuring effective same-gender peer group functioning and real world competence. Lastly, the theory extends to cover the adolescence period with issues ranging from personal identity, mixed-gender relationships to intimacy.

To put depth to the learners' social and emotional development, kapwa theory of Enriquez's (Pe-Pua \& Protacio-Marcelino, 2000) was considered as well. Here, the integration of values that are inherent to Filipinos was considered. The level of analysis in the social and emotional developmental characteristics of the learners explores the children's social psychology from a Filipino theory viewpoint. The characteristics were discussed in terms of the culture where the children were brought up (individualistic versus collectivistic), how the children relate to their peers (ibang-tao - hindi ibang tao) and values revolving around pakikipagkapwa (the process of defining one's shared identity), kagandahang-loob (shared inner nobility), karangalan (dignity), kalayaan (freedom), katarungan (social justice), pakikisama (getting along with others), katotohanan and katwiran (truth and reason), pagkakaisa (justice in unity), and kapayapaan (peace). The behavioral samples were paired with a Filipino value (e.g. pakikisama as palakaibigan) to put at the vantage point a characteristic that maybe seen as universal but inherently Filipino. The attributes of Filipino learners which can be drawn in this research provide data that will guide teachers, pre-service teachers, curriculum writers and other stakeholders of the education sector in their goals to provide relevant and quality instruction.

\subsection{Research questions}

The study aims to provide a comprehensive view of who the Filipino learner is. Specifically, it focuses on the following objectives:

$>$ Analyze the Filipino learners' attributes in terms of: a) Social; b) Emotional

$>$ Describe the developmental characteristics of Filipino learners through its psycho-social attributes.

\section{Methodology}

The study is a case study that focused on cross-sectional data of Filipino attributes. It used qualitative approach using opportunistic sampling for survey, interview, and observation. The research is composed of two (2) phases; the First Phase focused on mapping out the attributes of the learners by year level which were gathered from views of teachers, classroom observations, self-reports of learners, and interviews with parents and teachers. About 150 teachers were asked on the attributes of their learners in various subject areas. These views were gathered through seminar workshops held in the National Capital Region (NCR). 
On the other hand, learners per year level were selected in the campuses of a state university for teacher education and other private schools in NCR. Six (6) cases per level were chosen in the laboratory schools of a teacher education university which are located in Manila, Agusan, in Mindanao, Cadiz in the Visayas and Isabela in Northern Luzon. Sampling was purposive and stratified using criteria such as gender and age group of students. Parents and teachers of the cases were also interviewed to complete the process of triangulation. Time-motion study was also used as research technique to gather data about the routine of learners.

The Second Phase is the drawing of developmental characteristics of the learners using the social and emotional dimensions. The responses were used as behavior indicators and developmental characteristics of the Filipino learners in the different grade levels. Thematic and componential analyses of the responses were undertaken to consolidate and categorize the data using the areas of development.

\section{Findings and discussion}

\subsection{The Filipino Learners' Emotional Development}

Analysis of the learners' emotional development centered on behavior recording of the students in relating with their teachers and classmates, approaching tasks, and adjusting to changes in the school environment. The micro-behaviors were consolidated and translated into well-defined developmental characteristics and Filipino values were culled based on the characteristics.

The observed behaviors focused on interpersonal transactions with classmates and the emotions evoked during these transactions (See Table 1). In general, the kindergarten students were able to understand the concept of good and bad behavior, which may be an indication of the beginning of self-regulation and control. Because of their beginning understanding of complex emotions, the kindergarten students were also observed to demonstrate positive behaviors such as being fond of his or her classmates and negative emotions such as ignoring their noisy classmates. The students' observation revealed that they were well-regarded by their teachers and were seen to be enthusiastic participants in classroom-related tasks. The Filipino values generated from the characteristics can be summarized into being able to show what he or she feels and be able to explain how it is felt (pagpapakita ng nararamdaman), likewise, the kindergarten students displayed an awareness of what is happening around them and are capable of evaluating these in terms of whether it is appropriate or inappropriate (may kamalayan sa mga pangyayari). Lastly, the students were observed to be able to show positive emotions by being fond of their classmates (pagkamagiliw).

\section{Table 1}

Emotional Development Characteristics of Kinder and Primary School Learners

\begin{tabular}{|c|c|c|c|}
\hline Level & Micro Behaviors Observed & $\begin{array}{l}\text { Developmental } \\
\text { Characteristics }\end{array}$ & Filipino Values \\
\hline \multirow{4}{*}{ Kinder } & $\begin{array}{l}\text { Displays self-conscious behaviors by } \\
\text { continuously looking at the camera and } \\
\text { smiling at it. }\end{array}$ & \multirow{4}{*}{$\begin{array}{l}\text { Understands the concept of } \\
\text { good and bad behavior } \\
\text { Controls impulses } \\
\text { Demonstrates positive and } \\
\text { negative emotions towards } \\
\text { others }\end{array}$} & \multirow{4}{*}{$\begin{array}{l}\text { Pagpapakita ng nararamdaman } \\
\text { (Expresses what he or she feels) } \\
\text { May kamalayan sa mga pangyayari } \\
\text { (Is aware of what is happening) } \\
\text { Pagka-magiliw } \\
\text { (Affectionate) }\end{array}$} \\
\hline & $\begin{array}{l}\text { Is able to resist distractions made by } \\
\text { classmate and concentrate on singing and } \\
\text { following the teacher's commands. }\end{array}$ & & \\
\hline & $\begin{array}{l}\text { Can display fondness towards another } \\
\text { classmate by touching one's head. }\end{array}$ & & \\
\hline & $\begin{array}{l}\text { Is able to show boredom (yawning, looking } \\
\text { at other things, talking with classmates, } \\
\text { tinkering at a classmate's hair accessory) } \\
\text { when not interested in what is being } \\
\text { discussed. }\end{array}$ & & \\
\hline
\end{tabular}


The Filipino learner: A socioemotional perspective

Table 1 ... continued

\begin{tabular}{|c|c|c|c|}
\hline Level & Micro Behaviors Observed & $\begin{array}{l}\text { Developmental } \\
\text { Characteristics }\end{array}$ & Filipino Values \\
\hline \multirow{5}{*}{ Grade 1} & Affectionate & \multirow{5}{*}{$\begin{array}{l}\text { Demonstrates affection } \\
\text { Learns how to compromise }\end{array}$} & \multirow{5}{*}{$\begin{array}{l}\text { Magiliw (Affectionate) } \\
\text { Malambing (Affectionate) } \\
\text { Naipapahayag ang nararamdaman } \\
\text { (Is able to communicate how one } \\
\text { feels) }\end{array}$} \\
\hline & Sweet & & \\
\hline & Open to their feelings & & \\
\hline & Have fun while playing together & & \\
\hline & Have conflicting views with playmates & & \\
\hline \multirow{6}{*}{ Grade 2} & Shows excitement in participating in class & \multirow{6}{*}{$\begin{array}{l}\text { Displays an increasing } \\
\text { self-esteem (reciting, } \\
\text { participating) } \\
\text { Demonstrates positive } \\
\text { emotions towards tasks that } \\
\text { are perceived to be } \\
\text { enjoyable } \\
\text { Shows impulsive behaviors } \\
\text { such as getting mad and } \\
\text { being noisy }\end{array}$} & \multirow{6}{*}{$\begin{array}{l}\text { Pala-aral (Studious) } \\
\text { Masayahin (Cheerful) } \\
\text { Maramdamin (Sensitive) }\end{array}$} \\
\hline & Recites a lot & & \\
\hline & Showed interest in singing the song & & \\
\hline & $\begin{array}{l}\text { Showed interest. He's interested in singing } \\
\text { the song with movements and sometimes } \\
\text { shouted the first notes of the song }\end{array}$ & & \\
\hline & $\begin{array}{l}\text { Be mad for a while when things do not go } \\
\text { as planned }\end{array}$ & & \\
\hline & Often gets excited and noisy & & \\
\hline \multirow{14}{*}{ Grade 3} & Cheerful & \multirow{14}{*}{$\begin{array}{l}\text { Displays positive emotions } \\
\text { Demonstrates prosocial } \\
\text { behavior (e.g. empathy) } \\
\text { Prefers being praised and } \\
\text { complemented } \\
\text { Prefers to be with friends } \\
\text { Is aware of the importance } \\
\text { of following rules and } \\
\text { abiding with the law }\end{array}$} & \multirow{14}{*}{$\begin{array}{l}\text { Palakaibigan (Friendly) } \\
\text { Madaling makibagay (Can get } \\
\text { along with others) } \\
\text { Maalalahanin (Thoughtful) } \\
\text { May pagpapahalaga sa batas } \\
\text { (Values rules and laws) }\end{array}$} \\
\hline & Can easily adapt & & \\
\hline & Empathizes with other classmates & & \\
\hline & Very active & & \\
\hline & Prefers to hear complements & & \\
\hline & Appreciate and give importance the law. & & \\
\hline & $\begin{array}{l}\text { When not involved acknowledged in a } \\
\text { discussion, the student would not share his } \\
\text { or her thoughts and opinions }\end{array}$ & & \\
\hline & Street smart & & \\
\hline & Laging tahimik. & & \\
\hline & Likes to be around friends & & \\
\hline & Thoughtful & & \\
\hline & $\begin{array}{l}\text { They learn to approach their classmates' } \\
\text { ideas. }\end{array}$ & & \\
\hline & $\begin{array}{l}\text { Shares feelings about issues concerning the } \\
\text { society and the environment }\end{array}$ & & \\
\hline & Can formulate ideas. & & \\
\hline
\end{tabular}

With regard the first grade students, in general understand how they feel about themselves. Based on the observations students between 6 to 7 years old are affectionate and sweet to their parents, teachers and playgroup. They also learn how to control their impulses and learn how to compromise with their playmates. The Filipino values focused on being fond (magiliw) of their playmates in general, are more pronounced in showing their affection towards others (malambing) and are able to say what they feel (naipapahayag ang nararamdaman). On the other hand, grade two students were observed to display an increasing self-esteem by reciting, participating and being involved in a number of curricular and co-curricular activities. They also demonstrate positive emotions towards tasks that are enjoyable and are open in expressing tasks that they are happy to do. However, because of the capacity to decide on what makes them happy, the students between 7 to 8 years old tend to become impulsive in their decisions and may pass as being difficult to manage inside the classroom. The Filipino values of being studious (pala-aral), cheerful (masayahin) and sensitive (maramdamin) were salient in the growing child, specifically among Filipino families, it is in this stage where they see their children being active and may sometimes become stubborn in expressing their needs. However, many Filipino families provide tasks and roles to children in this age and is seen to be a rite of passage to becoming a responsible family member.

The third grade students displayed positive emotions and prefers to be with their friends in most in- and after-school activities. Students were observed to empathize with their classmates, adapt with new school conditions such as adding more friends, prefer to hear complements and be able to work things through when there is a conflict. Filipino values include being friendly (palakaibigan), easy to be with and can adapt to different companions (madaling makibagay), and thoughtful (maalahanin).

Table 2 discusses the emotional development characteristics of learners in the intermediate level which 
covers students in Grade 4 to Grade 6 (approximately between 9 to 11 years old). Stretching through middle childhood, this developmental stage is characterized by a formal and an informal integration to the society as depicted by the transactions inside the classroom and relationships in the community. The children in Grade 4 , in general were observed to display self-conscious emotions, characterized by being very particular with their outputs, and becoming frustrated when what he or she plans does not turn out well. The students were likewise observed to be creative with the tasks that they undertake, however, there is also the tendency to give up when the tasks seem difficult to accomplish. In general, the students observed showed positive emotions towards relating with others and doing different activities.

The Grade 5 students were observed to show compassion and affection particularly with their families and friends; is strong willed, values other people's emotions which is congruent with their preference to show affection, is nationalistic, and is aware of the consequences of his or her actions. As the children's social relationships expands, their capacity to see beyond their egocentric thoughts increases. They are more capable of resolving their differences and are beginning to understand the magnitude or extent of decisions or actions they do. The Grade 6 students, on the other hand, were seen to demonstrate more complex prosocial behaviors such as perspective-taking, empathy and engagement in compromise-related discussions. They were also seen to be resilient especially when problems involved family matters. They are determined, aware of appropriate behaviors and has a higher tendency to forgive those who transgressed him or her.

When it came to analyzing the developmental characteristics and translating it to Filipino values, the values that were culled from the observations centered on being hardworking (matiyaga), to questions related to one's capacities or competence (mahina ang loob). The myriad of Filipino values being developed and enhanced during this developmental stage suggests the child's growing capacity for complex emotions (e.g. malikhain and mahina ang loob). It can be induced that children in this stage are growing towards achieving clearer goals and better integration of needs and values such as in expressing fondness towards significant others (mapagmahal) which is interpersonal to a more societal level such as showing patriotism and nationalism (makakabayan) and concerned with nature (makakalikasan). This stage which is considered as passing through from childhood to adolescence emphasizes that opportunities for becoming mature should be provided, however, such maturing is not automatic, so therefore the significant others must carefully engineer the experiences where the values would be developed.

\section{Table 2}

Emotional Development Characteristics of Intermediate Students (Grades 4 to 6)

\begin{tabular}{|c|c|c|c|}
\hline Level & Micro Behaviors Observed & $\begin{array}{l}\text { Developmental } \\
\text { Characteristics }\end{array}$ & Filipino Values \\
\hline \multirow{8}{*}{$\begin{array}{c}\text { Grade } \\
4\end{array}$} & Shy and quiet the whole time & \multirow{8}{*}{$\begin{array}{l}\text { Displays self-conscious } \\
\text { behaviors } \\
\text { Demonstrates a high level } \\
\text { of self-expression in tasks } \\
\text { at hand } \\
\text { Tends to give up easily on } \\
\text { tasks that may seem } \\
\text { difficult to accomplish } \\
\text { Shows positive emotions } \\
\text { towards activities } \\
\text { accomplished }\end{array}$} & \multirow{8}{*}{$\begin{array}{l}\text { Masigasig/Matiyaga (Persevering) } \\
\text { Masayahin (Cheerful) } \\
\text { Mahina ang loob (Weak-spirited) } \\
\text { Malikhain (Creative) }\end{array}$} \\
\hline & $\begin{array}{l}\text { He was very excited and showed much } \\
\text { enthusiasm. }\end{array}$ & & \\
\hline & $\begin{array}{l}\text { Starting a composition was very natural; he } \\
\text { didn't think about it much but acted } \\
\text { through feeling. }\end{array}$ & & \\
\hline & $\begin{array}{l}\text { Worked impulsively and expressively. In } \\
\text { this process, she composes very well. She } \\
\text { has a very positive attitude }\end{array}$ & & \\
\hline & $\begin{array}{l}\text { She finished the project although it may be } \\
\text { seen that she was not quite satisfied with } \\
\text { the end product }\end{array}$ & & \\
\hline & $\begin{array}{l}\text { She finished the project with satisfaction. } \\
\text { She was able to apply what she learned. }\end{array}$ & & \\
\hline & He gave up easily & & \\
\hline & $\begin{array}{l}\text { He finished the project happily and then } \\
\text { submitted it with much enthusiasm }\end{array}$ & & \\
\hline
\end{tabular}


The Filipino learner: A socioemotional perspective

Table 2 ... continued

\begin{tabular}{|c|c|c|c|}
\hline Level & Micro Behaviors Observed & $\begin{array}{l}\text { Developmental } \\
\text { Characteristics } \\
\end{array}$ & Filipino Values \\
\hline \multirow{8}{*}{$\begin{array}{c}\text { Grade } \\
5\end{array}$} & Compassionate & \multirow{8}{*}{$\begin{array}{l}\text { Shows compassion and } \\
\text { affection } \\
\text { Is strong-willed } \\
\text { Values other people's } \\
\text { emotions and opinions } \\
\text { Demonstrates } \\
\text { nationalism-related } \\
\text { behaviors } \\
\text { Is aware of the } \\
\text { consequences of his or her } \\
\text { actions }\end{array}$} & \multirow{8}{*}{$\begin{array}{l}\text { Mapagmahal (Loving) } \\
\text { Maunawain (Understanding) } \\
\text { Matatag ang loob (Strong-willed) } \\
\text { Makabayan (Nationalistic) } \\
\text { Makakalikasan (Environmentally } \\
\text { aware) } \\
\text { Mapagpasensya (Patient) }\end{array}$} \\
\hline & $\begin{array}{l}\text { A very loving person especially to his/her } \\
\text { family and friends }\end{array}$ & & \\
\hline & Has a strong will & & \\
\hline & Values other people's feelings or emotions & & \\
\hline & Sensitive to one's own surroundings & & \\
\hline & Shows Nationalism and Patriotism & & \\
\hline & Learns to accept his/her mistakes & & \\
\hline & Patient & & \\
\hline \multirow{7}{*}{$\begin{array}{c}\text { Grade } \\
\quad 6\end{array}$} & Values other people's feelings or emotions & \multirow{7}{*}{$\begin{array}{l}\text { Demonstrates prosocial } \\
\text { behaviors } \\
\text { Displays resilient-related } \\
\text { behaviors } \\
\text { Is determined } \\
\text { Is aware of appropriate } \\
\text { behaviors } \\
\text { Forgives those who had } \\
\text { done him or her wrong }\end{array}$} & \multirow{7}{*}{$\begin{array}{l}\text { May pagpapahalaga sa kapwa (Is } \\
\text { sensitive to the needs of others) } \\
\text { May positibong pananaw (has a } \\
\text { positive perspective about life) }\end{array}$} \\
\hline & Helpful or charitable & & \\
\hline & $\begin{array}{l}\text { Remains strong in times of challenges or } \\
\text { problems }\end{array}$ & & \\
\hline & Determined person & & \\
\hline & Has good manners & & \\
\hline & Humanitarian type of person & & \\
\hline & Forgiving & & \\
\hline
\end{tabular}

Table 2 provides the behaviors reported by the learners, their teachers and parents when it came to how learners in Grades 7 to 10 relate to themselves and their significant others. Salient among the characteristics mentioned is the increasing tendency of the high school students to be more open with and accountable for their feelings. The students were observed to be exploring their identities through giving opinions on various issues (Grade 7); engaging activities where they would be appreciated (Grade 8); being more affectionate and thoughtful (Grade 9); while having conflicting feelings between expressing what they feel or not (Grade 10). The progression and issues confronted by adolescent learners pose problems which when overcome would serve as a formal rite of passage to adulthood. It is interesting to note that one of the observed characteristics among adolescent learners focused on displaying values that are relevant to Filipinos such as being respectful and mindful of what others will say in making decisions, in this case, one of the decisions would involve the course that the learner would pursue in college.

Table 3

Emotional Development Characteristics of High School Students (Grades 7 to 10)

\begin{tabular}{|c|c|c|c|}
\hline Level & Micro Behaviors Observed & $\begin{array}{l}\text { Developmental } \\
\text { Characteristics } \\
\end{array}$ & Filipino Values \\
\hline \multirow{14}{*}{ Grade 7} & Is idealistic in his/her opinions & \multirow{14}{*}{$\begin{array}{l}\text { Explores his or her identity } \\
\text { through giving opinions on } \\
\text { issues and forming } \\
\text { perceptions among } \\
\text { classmates } \\
\text { Expresses feelings openly } \\
\text { and has an increasing } \\
\text { self-esteem } \\
\text { Displays values that are } \\
\text { relevant among Filipinos }\end{array}$} & \multirow{14}{*}{$\begin{array}{l}\text { Marunong tumanggap ng } \\
\text { pagkakamali (Accepts his or her } \\
\text { own shortcomings) } \\
\text { Magalang (Respectful) } \\
\text { Masayahin (Cheerful) } \\
\text { Matatag (Strong) } \\
\text { May malasakit sa kapwa } \\
\text { (Altruistic) } \\
\text { Responsible } \\
\text { May tiwala sa sarili (Confident) }\end{array}$} \\
\hline & $\begin{array}{l}\text { Expresses appreciation in the various } \\
\text { discussions of topics inside the classroom }\end{array}$ & & \\
\hline & Sensitive & & \\
\hline & $\begin{array}{l}\text { Seeks attention from classmates and } \\
\text { teachers }\end{array}$ & & \\
\hline & $\begin{array}{l}\text { Shows an understanding of how the past } \\
\text { affects the future }\end{array}$ & & \\
\hline & Respects his or her teachers & & \\
\hline & Expresses one's feelings clearly. & & \\
\hline & $\begin{array}{l}\text { Displays values that are relevant to the } \\
\text { Filipino race (respectful, empathetic) }\end{array}$ & & \\
\hline & Accepts and admits wrongdoings & & \\
\hline & Cheerful & & \\
\hline & Is strong in times of adversities. & & \\
\hline & $\begin{array}{l}\text { Gives pieces of advice to peers and serves } \\
\text { as an inspiration to other classmates }\end{array}$ & & \\
\hline & Is confident & & \\
\hline & $\begin{array}{l}\text { Has an increased self-esteem upon finishing } \\
\text { a project }\end{array}$ & & \\
\hline
\end{tabular}


Table 3 ... continued

\begin{tabular}{|c|c|c|c|}
\hline Level & Micro Behaviors Observed & $\begin{array}{l}\text { Developmental } \\
\text { Characteristics } \\
\end{array}$ & Filipino Values \\
\hline \multirow{8}{*}{ Grade 8} & Cheerful & \multirow{8}{*}{$\begin{array}{l}\text { Displays positive emotions } \\
\text { when in peer groups } \\
\text { Engages in activities that } \\
\text { would earn the appreciation } \\
\text { of significant others } \\
\text { Sympathizes with } \\
\text { classmates } \\
\text { Values tasks given in school }\end{array}$} & \multirow{8}{*}{$\begin{array}{l}\text { Masayahin (Cheerful) } \\
\text { May malasakit sa kapwa } \\
\text { (Altruistic) } \\
\text { Nagpapahayag ng saloobin } \\
\text { (Expresses how one feels) } \\
\text { Responsible } \\
\text { Masinop (Prudent) } \\
\text { May tiwala sa sarili (Self-confident) } \\
\text { May pagpapahalaga sa natutunan } \\
\text { (Values learning) }\end{array}$} \\
\hline & Show empathy. & & \\
\hline & $\begin{array}{l}\text { Appreciate what they have learned through } \\
\text { valuing process. }\end{array}$ & & \\
\hline & $\begin{array}{l}\text { Does tasks that would make significant } \\
\text { others happy (e.g. baking) }\end{array}$ & & \\
\hline & $\begin{array}{l}\text { Expresses excitement in undertaking new } \\
\text { tasks }\end{array}$ & & \\
\hline & $\begin{array}{l}\text { Shows deep interest in understanding the } \\
\text { functions of computers and other electronic } \\
\text { gadgets. }\end{array}$ & & \\
\hline & Sympathizes with classmates & & \\
\hline & Expresses feelings effectively & & \\
\hline \multirow{13}{*}{ Grade 9} & $\begin{array}{l}\text { Reconciles emotions towards saving the } \\
\text { environment and the technology }\end{array}$ & \multirow{13}{*}{$\begin{array}{l}\text { Sympathizes with other } \\
\text { people especially when it } \\
\text { comes to family-related } \\
\text { concerns } \\
\text { Is becoming more } \\
\text { expressive, affectionate and } \\
\text { thoughtful with significant } \\
\text { others } \\
\text { Empathizes with peers and } \\
\text { other people } \\
\text { Displays a growing capacity } \\
\text { to control emotions }\end{array}$} & \multirow{13}{*}{$\begin{array}{l}\text { Makabayan (Nationalistic) } \\
\text { Makakalikasan } \\
\text { (Environmentally-concerned) } \\
\text { May malasakit sa kapwa } \\
\text { (Altruistic) } \\
\text { Pagsasantabi ng sariling } \\
\text { Kapakanan (Altruistic) } \\
\text { May pagpapahalaga sa kulturang } \\
\text { banyaga (Values foreign concepts } \\
\text { and culture) } \\
\text { Maalalahanin (Thoughtful) } \\
\text { Malambing (Affectionate) } \\
\text { May simpatya (Demonstrates } \\
\text { sympathy) } \\
\text { Maunawain (Understanding) } \\
\text { Mapagmahal (Loving) } \\
\text { Sensitibo (Sensitive) }\end{array}$} \\
\hline & $\begin{array}{l}\text { Shows awe in learning new things about the } \\
\text { environment. }\end{array}$ & & \\
\hline & $\begin{array}{l}\text { Sympathizes with what other people are } \\
\text { going through }\end{array}$ & & \\
\hline & $\begin{array}{l}\text { Is able to put aside family problems when } \\
\text { at school }\end{array}$ & & \\
\hline & Thoughtful & & \\
\hline & Affectionate & & \\
\hline & Expresses emotions in creative ways & & \\
\hline & $\begin{array}{l}\text { Understand others in different or difficult } \\
\text { situations }\end{array}$ & & \\
\hline & Is diligent in completing school works & & \\
\hline & Controls emotions & & \\
\hline & Becomes more patient in handling issues & & \\
\hline & $\begin{array}{l}\text { Know how to appreciate whatever finish } \\
\text { product they have. }\end{array}$ & & \\
\hline & $\begin{array}{l}\text { Know how to accept and appreciate } \\
\text { suggestions for a work not well done. }\end{array}$ & & \\
\hline \multirow{12}{*}{$\begin{array}{c}\text { Grade } \\
10\end{array}$} & $\begin{array}{l}\text { Values other people especially in group } \\
\text { works and assignments }\end{array}$ & \multirow{12}{*}{$\begin{array}{l}\text { Recognizes the role of each } \\
\text { members of a group } \\
\text { Has conflicting feelings } \\
\text { between voicing out their } \\
\text { emotions and giving their } \\
\text { opinions } \\
\text { Is able to share feelings } \\
\text { with a trusted peer group } \\
\text { Displays the ability to } \\
\text { handle emotions effectively }\end{array}$} & \multirow{12}{*}{$\begin{array}{l}\text { May kamalayang pang-ekonomiya } \\
\text { (Is aware of economic issues) } \\
\text { Masayahin (Cheerful) } \\
\text { Agresibo (Aggressive) } \\
\text { Malawak na pang-unawa } \\
\text { (Demonstrates perspective-taking) } \\
\text { May pagpapahalaga sa } \\
\text { nararamdaman ng iba (Values how } \\
\text { others feel) } \\
\text { May kontrol sa emosyon (Controls } \\
\text { one's emotions) } \\
\text { Maunawain (Understanding) } \\
\text { Nakikipagkaisa (Cooperates with } \\
\text { others) } \\
\text { Matiyaga (Persevering) }\end{array}$} \\
\hline & $\begin{array}{l}\text { Expresses opinions about emotional issues } \\
\text { (love, relationships) }\end{array}$ & & \\
\hline & Finds it difficult to voice out feelings & & \\
\hline & $\begin{array}{l}\text { Is easily persuaded because of emotional } \\
\text { influence }\end{array}$ & & \\
\hline & $\begin{array}{l}\text { Understands what is happening in the } \\
\text { community }\end{array}$ & & \\
\hline & Is able to lead classmates & & \\
\hline & Cheerful & & \\
\hline & $\begin{array}{l}\text { Demonstrates love for the family by } \\
\text { understanding what the family is going } \\
\text { through. }\end{array}$ & & \\
\hline & $\begin{array}{l}\text { Can share his or her feelings when } \\
\text { discussing. }\end{array}$ & & \\
\hline & $\begin{array}{l}\text { Understands differences in attitudes among } \\
\text { peers and classmates and is able to } \\
\text { understand his or her peers' emotions }\end{array}$ & & \\
\hline & Handles emotions effectively & & \\
\hline & Eagerness and excitement to learn. & & \\
\hline
\end{tabular}

The Grade 7 students were characterized to express their feelings openly and has an increasing self-esteem. This, however, is relative to how the peer group would accept their being open about their feelings which could lead to a positive or negative view of the person. On the other hand, the Grade 8 students were observed to display positive emotions among their peer groups which may affect the relationships they have with their 
parents. The conflicting values - their parents' and their friends' would put the learner in a situation where he or she chooses to forego what he/she considers important- whether that may be choosing his or her peers over his or her parents. The Grade 9 students were characterized to sympathize with other people, interestingly; one of the reported behaviors was their ability to empathize too. The capacity to sympathize centers on sharing the emotions such as in crying with the person who is going through a difficult situation, while empathizing would look into understanding how the person feels and providing support during the difficult situation. The learners in this stage are able to put things in perspective in relation to reflecting on how he or she would feel given another person's situation, which is indicative of a maturing sense of cognition. Lastly, Grade 10 learners were described as being able to recognize the role of each members of a group, is able to share feelings with a trusted group, and displays an increased ability in handling emotions which are precursors to more complex challenges and decisions they have to face and make when they enter adulthood.

When it came to the Filipino values, the students were observed to be able to acknowledge their mistakes and be responsible for them (marunong tumanggap ng pagkakamali), respectful of others (magalang), cheerful (masayahin), strong in character (matatag), and has a growing sense of looking out for others (may malasakit sa kapwa). These Filipino values were consistently observed across the grade levels which reflect how both the family and the teachers are molding and educating the adolescents in terms of emotional development.

When it comes to understanding the context of development among Filipino learners, it is noteworthy that the learners show affection to their caregivers at an early age. This type of attachment with their significant others serve as sounding board to emotions that would later on provide scaffolding to more matured emotions. The affection-related emotions displayed during their primary years may be inferred to lead to emotions indicative of understanding, loving and persevering which would later on move on to being able to control one's emotions and valuing how others feel. The socialization from parents and significant others provide the learners a more comprehensive view of how to handle emotions and the assumed response of the people they will be dealing with. Filipinos value pakikipagkapwa (shared identity with others) which is reflected in emotions that are felt and developed among children, the values they develop are transmitted from one developmental stage to another highlighting the need to relate with others and be able to maintain relationships.

\subsection{Social Development}

Children's characteristic were analyzed by clusters with the following grouping: (a) primary consisting of students in kinder up to Grade 3; (b) intermediate composed of students from grades 4 to 6; and (c) junior high school who were made up of students from first year to fourth year high school.

\section{Table 4}

The Social Characteristics of Children in the Primary Grades

\begin{tabular}{|c|c|c|c|}
\hline Level & Micro Behaviors Observed & $\begin{array}{l}\text { Developmental } \\
\text { Characteristics }\end{array}$ & Filipino Values \\
\hline \multirow{7}{*}{ Kinder } & $\begin{array}{l}\text { Is able to sing and interact with a partner as } \\
\text { required in the song. }\end{array}$ & \multirow{7}{*}{$\begin{array}{l}\text { Acknowledges the roles that } \\
\text { others make in performing } \\
\text { activities } \\
\text { Is capable of expressing } \\
\text { oneself when distressed by } \\
\text { classmates/peers } \\
\text { Is aware of social scripts } \\
\text { and uses it } \\
\text { Demonstrates socially } \\
\text { appropriate behaviors }\end{array}$} & \multirow{7}{*}{$\begin{array}{l}\text { May kamalayan sa role-taking (Is } \\
\text { aware of role-taking) } \\
\text { Naipapahayag ang damdamin } \\
\text { (Expresses how one feels) }\end{array}$} \\
\hline & Interacts with the teacher while singing. & & \\
\hline & $\begin{array}{l}\text { Responds when called and asked by the } \\
\text { teacher. }\end{array}$ & & \\
\hline & $\begin{array}{l}\text { Is able to raise personal concerns to the } \\
\text { teacher (e.g. if someone is taunting him or } \\
\text { her). }\end{array}$ & & \\
\hline & $\begin{array}{l}\text { Is aware and can display social scripts (e.g. } \\
\text { "Good morning Teacher Pam.") }\end{array}$ & & \\
\hline & $\begin{array}{l}\text { Demonstrates socially appropriate behavior } \\
\text { when being reprimanded by the teacher } \\
\text { (when the class gets noisy). }\end{array}$ & & \\
\hline & Understands the concept of 'behave.' & & \\
\hline
\end{tabular}


Rungduin, T. T., \& Reyes, Z. Q.

Table 4 ... continued

\begin{tabular}{|c|c|c|c|}
\hline Level & Micro Behaviors Observed & $\begin{array}{l}\text { Developmental } \\
\text { Characteristics } \\
\end{array}$ & Filipino Values \\
\hline \multirow{7}{*}{ Grade 1} & Easily make friends & \multirow{7}{*}{$\begin{array}{l}\text { Establishes friendships } \\
\text { Becomes aware of peers' } \\
\text { opinions } \\
\text { Develops hobbies and } \\
\text { demonstrates interest in } \\
\text { play } \\
\text { Wants recognition for } \\
\text { individual achievement }\end{array}$} & \multirow{7}{*}{$\begin{array}{l}\text { Palakaibigan (Friendly) } \\
\text { May kamalayan sa pananaw ng iba } \\
\text { (Demonstrates perspective-taking) } \\
\text { Paglinang ng interes (Enhances } \\
\text { one's interests) } \\
\text { Nais makilala sa kakayahan (Needs } \\
\text { to be acknowledged/recognized) }\end{array}$} \\
\hline & $\begin{array}{l}\text { Wants recognition for individual } \\
\text { achievements. }\end{array}$ & & \\
\hline & $\begin{array}{l}\text { Interested in friends and is not influenced } \\
\text { by their social or economic status }\end{array}$ & & \\
\hline & Gets greater enjoyment from group play & & \\
\hline & Starts collections. & & \\
\hline & $\begin{array}{l}\text { Are becoming increasingly aware of peers' } \\
\text { opinions }\end{array}$ & & \\
\hline & Observes people around them & & \\
\hline \multirow[b]{3}{*}{ Grade 2} & Talks with classmates & \multirow{3}{*}{$\begin{array}{l}\text { Is able to clearly } \\
\text { communicate with teachers } \\
\text { and classmates } \\
\text { Enthusiastically engages in } \\
\text { classroom activities and } \\
\text { outdoor games }\end{array}$} & \multirow{3}{*}{$\begin{array}{l}\text { Pagkamadaldal (Talkative) } \\
\text { Pakikiisa sa gawain sa paaralan } \\
\text { (Cooperates with schoolwork) }\end{array}$} \\
\hline & Talks with the teachers & & \\
\hline & $\begin{array}{l}\text { Engages in class activities and outdoor } \\
\text { games }\end{array}$ & & \\
\hline \multirow{16}{*}{ Grade 3} & Knows how to mingle with her classmates. & \multirow{16}{*}{$\begin{array}{l}\text { Participates in peer-related } \\
\text { tasks } \\
\text { Is aware of } \\
\text { socially-appropriate } \\
\text { behaviors needed to } \\
\text { establish friendships } \\
\text { Is interested in studying } \\
\text { Prefers to be with people } \\
\text { who share the same } \\
\text { interests } \\
\text { Becomes pro-social in } \\
\text { dealing with peers (helps, } \\
\text { cooperates, shares) } \\
\text { Have opposite sex peers } \\
\text { Is attentive in class and } \\
\text { participates in class } \\
\text { discussions }\end{array}$} & \multirow{16}{*}{$\begin{array}{l}\text { Palakaibigan (Friendly) } \\
\text { Pala-aral (Studious) } \\
\text { Marunong (Well-informed) } \\
\text { Magaling makisama (Gets along } \\
\text { with others) } \\
\text { Matulungin (Helpful) } \\
\text { Aktibo sa klase (Active in class) }\end{array}$} \\
\hline & Plays actively with his peers. & & \\
\hline & Had a hard time to get along with others. & & \\
\hline & Can cooperate with other children & & \\
\hline & Friendly & & \\
\hline & Can easily mingle without hesitation.. & & \\
\hline & Help other classmates. & & \\
\hline & $\begin{array}{l}\text { Can deal with classmates whether girl or } \\
\text { boy. }\end{array}$ & & \\
\hline & Displays diligence in studying & & \\
\hline & $\begin{array}{l}\text { Can mingle with people with the same kind } \\
\text { of attitude (preferences) }\end{array}$ & & \\
\hline & $\begin{array}{l}\text { May display aloof-behaviors (not wanting } \\
\text { to talk with others) }\end{array}$ & & \\
\hline & $\begin{array}{l}\text { Can effectively interact with the opposite } \\
\text { sex }\end{array}$ & & \\
\hline & Behaves well with other people & & \\
\hline & Interacts only with her friends in the class. & & \\
\hline & Participates in class discussions & & \\
\hline & Has many friends & & \\
\hline
\end{tabular}

The children in kindergarten and in first grade were between 5 to 6 or 7 years old whose emerging characteristics focused on developing perspective taking by acknowledging the roles others make in performing tasks and other activities. These were seen in observations when the students listened to the teacher who was demonstrating the way a song will be sang and the actions that accompany it. The observed children also took turns in performing the song, with each child waiting for his or her partner to complete a task before acting the song. It was also observed that the children were able to call their teacher and student teachers' attention when their classmates interrupted what they are doing or had displayed misbehaviors. The children were also observed to be displaying behaviors that were considered to be socially appropriate such as greeting the teacher and stopping from tasks that are unrelated to the activity.

Data regarding the second and third graders whose ages were between 7 to 8 or 9 years old suggest a growing concern for forming friendships and becoming involved in hobbies and pursuing their interests. The observed behaviors were translated into characteristics that involved establishing friendships, becoming aware of their peers' opinions, developing hobbies and demonstrating interest in play, and displaying behaviors of wanting to be recognized for their achievements. Classroom observations revealed that the first graders showed preference on the students whom they would like to work with when it comes to group tasks, and it was also observed that the children they were commonly closest to were their seatmates and those they usually go home with. 
The data regarding the primary students was linked to a developmental theory that would universally approximate the children's characteristic. Erikson's psychosocial development was chosen because of the tasks and virtues it presented. In general, the primary school children's characteristics can be indicators of the growing sense of initiative, which is characterized by acting as grown-ups and accepting responsibilities (Thomas, 2005). It was observed that the children began to assert their power and control over the world through directing play and other social interaction. Children need to begin asserting control and power over the environment by taking initiative by planning activities, accomplishing tasks and facing challenges. Play and imagination had taken an important role at this stage. They had also internalized the virtue of purpose, which focuses on finding meaning to the activities being engaged to and activities being done. Lastly, the characteristics can be generally explained by Erikson's Industry versus Inferiority stage where the children had begun to work on activities that interest them. The characteristics extracted from the observations show a growing tendency to form meaningful friendships; while congruent to the establishing relationships is the need to be recognized in a field that the child is good in which enhances the virtue of competence among them.

When it came to describing the Filipino learner, it can be surmised that the learners have an increasing awareness of role-taking (may kamalayan sa role-taking), which can be linked to the characterizing the culture of Filipinos as being collectivistic where the roles each member of the family play is integral to the functioning of the unit. The beliefs such as not permitting children to give their opinions when adults are talking would provide the children an understanding of the delineation of their roles as children and the roles of those who are older take, however, when children speak, the adults would say - "parang matanda magsalita" (she/he speaks like a person of wisdom) which provides the child greater awareness of how he or she should look at situations from different points of view. Another Filipino value that emerged in characterizing the child revolves on being able to express how one feels (naipapahayag ang damdamin). Although children in traditional families are not allowed to air their feelings, some families provide opportunities for their children to tell and say what they want in the process of teaching assertiveness and enhancing the child's "tibay ng loob." The first graders were described to be friendly "palakaibigan" and like the preschoolers are capable of perspective-taking. Along with the development of perception is the development of interest when it came to where he or she could be competent in (nais makilala sa kakayahan). These two characteristics of the Filipino learner in preschool and first grade highlight that the Filipino values still resurfaces in the midst of technological innovations and mixing of varied cultures.

When it came to the Filipino values emerging on the collected data among the second and third graders, "pagkamadaldal" and "palakaibigan" were salient characteristics. This would be congruent with the notion that as the children's social environment expands, the children are able to form meaningful relationships and be competent in it through exchanging thoughts and discussing issues.

\section{Table 5}

The Social Characteristics of Children in the Intermediate Grades

\begin{tabular}{|c|c|c|c|}
\hline Level & Micro Behaviors Observed & $\begin{array}{l}\text { Developmental } \\
\text { Characteristics }\end{array}$ & Filipino Values \\
\hline \multirow{6}{*}{ Grade 4} & Does not talk much with his seatmates & \multirow{6}{*}{$\begin{array}{l}\text { Is capable of concentrating } \\
\text { on a task } \\
\text { Displays prosocial } \\
\text { behaviors that may } \\
\text { strengthen ties with } \\
\text { age-group } \\
\text { Demonstrates the ability to } \\
\text { introspect }\end{array}$} & \multirow{6}{*}{$\begin{array}{l}\text { Pagka-mapagsiyasat (Is inquisitive) } \\
\text { Pinipiling maging mapag-isa } \\
\text { (Prefers to work alone) } \\
\text { Pagkamadaldal (Talkative) } \\
\text { Pagka-matuon sa Gawain (Focuses } \\
\text { on tasks that should be done) }\end{array}$} \\
\hline & $\begin{array}{l}\text { She shares materials (water, watercolor) } \\
\text { with other kids at the table }\end{array}$ & & \\
\hline & $\begin{array}{l}\text { He enjoys talking/joking a lot with his } \\
\text { seatmates while working }\end{array}$ & & \\
\hline & Chats casually with some classmates & & \\
\hline & $\begin{array}{l}\text { He does not talk much with others. He } \\
\text { smiles around but is quiet }\end{array}$ & & \\
\hline & $\begin{array}{l}\text { Interacts with his seatmates and looks at the } \\
\text { teacher when discussing }\end{array}$ & & \\
\hline
\end{tabular}


Table 5 ... continued

\begin{tabular}{|c|c|c|c|}
\hline Level & Micro Behaviors Observed & $\begin{array}{l}\text { Developmental } \\
\text { Characteristics }\end{array}$ & Filipino Values \\
\hline \multirow{11}{*}{ Grade 5} & Can effectively interact with others & \multirow{11}{*}{$\begin{array}{l}\text { Displays prosocial } \\
\text { behaviors towards } \\
\text { age-group and others } \\
\text { Develops friendships and } \\
\text { aims to maintain it. } \\
\text { Participates in religious } \\
\text { activities of the school } \\
\text { Demonstrates the tendency } \\
\text { to be easily influenced by } \\
\text { others }\end{array}$} & \multirow{11}{*}{$\begin{array}{l}\text { Pakikisama (Goes along with } \\
\text { others) } \\
\text { Pakikipag-palagayang loob } \\
\text { (Establishes good relationships) } \\
\text { May pagpapakatao (Shows concern } \\
\text { about others, respects the rights of } \\
\text { others) } \\
\text { Palakaibigan (Friendly) } \\
\text { Matulungin (Helpful) }\end{array}$} \\
\hline & Is able to converse with others. & & \\
\hline & Displays sensitivity in the needs of others & & \\
\hline & Participates in activities & & \\
\hline & Is able to form friendships with others & & \\
\hline & $\begin{array}{l}\text { Cooperates and participates in class } \\
\text { activities }\end{array}$ & & \\
\hline & $\begin{array}{l}\text { Displays emotions relevant to being } \\
\text { humane with others }\end{array}$ & & \\
\hline & $\begin{array}{l}\text { Actively participates in the religious } \\
\text { activities in school }\end{array}$ & & \\
\hline & $\begin{array}{l}\text { Social relationships tend to be affected by } \\
\text { long hours devoted to playing computers }\end{array}$ & & \\
\hline & Helpful in the family and the community & & \\
\hline & Shows loving behaviors with others & & \\
\hline \multirow{6}{*}{ Grade 6} & Shares his or her knowledge in class & \multirow{6}{*}{$\begin{array}{l}\text { Displays prosocial } \\
\text { behaviors towards others } \\
\text { Is able to discuss an issue } \\
\text { effectively } \\
\text { Joins community and } \\
\text { school activities }\end{array}$} & \multirow{6}{*}{$\begin{array}{l}\text { Matulungin (Helpful) } \\
\text { Mapag-kawanggawa (Charitable) } \\
\text { Pakikisama (Goes along with others } \\
\text { well) } \\
\text { Makabayan (Nationalistic) }\end{array}$} \\
\hline & Interacts with others effectively & & \\
\hline & Discusses issues effectively & & \\
\hline & Charitable & & \\
\hline & Prefers to play & & \\
\hline & Joins community and school activities & & \\
\hline
\end{tabular}

The table shows the consolidated observations from teachers and parents as well as self-reports of the students. It can be surmised that the learners in the intermediate level had a growing sense of being involved as well as involving others in their interests. The fourth graders had transitioned from the egocentric notion of Piaget to being more sensitive of others' needs. This social characteristic on the other hand progresses as the learner enters the fifth and sixth grade because concern for age-group peers expands to the community and school in general. The child becomes a socially-empathic individual who becomes charitable and nationalistic by the sixth grade which could be considered as a rite of passage to adolescence.

Theory-wise, the developmental characteristics displayed by learners in the intermediate level emulate the culmination of Erikson's industry versus inferiority where the students' feelings of competence become enhanced as they explore relationships outside the ones that they had already formed. This may seem to be ideal; however, the connections may have its pitfalls such as allowing oneself to be strongly influenced by peers in terms of doing what is not appropriate, such as playing computer games and being consumed in it. Prior data on the students' context revealed that technological gadgets were a part of a learner's after school activities.

Lastly, analyses of the Filipino values emerging from the developmental characteristics reveal values pertaining to being more introspective of what was learned (pagka-mapagsiyasat). This value being congruent with Piaget's cognitive development theory pertaining to a learner's increasing curiosity in testing hypotheses. As a Filipino trait, being introspective (pagka-mapagsiyasat) provides an opportunity to examine the environment and be more sensitive of its cues. This may lead to wanting to be alone for some time (pinipiling mapag-isa) which could be based on wanting to concentrate on a atask (pagtuon sa gawain). As the social world expands, the children's relationships extend and with this the basics of "kapwa" or shared identity with others increases. The child learns to get along with peers and other children of various age groups (pakikisama) and begins to form lasting friendships. The child also begins to explore his or her identity as a community member involved in the development of his or her community in particular and nation in general. 
The Filipino learner: A socioemotional perspective

Table 6

The Social Characteristics of Learners in Junior High School

\begin{tabular}{|c|c|c|c|}
\hline Level & Micro Behaviors Observed & $\begin{array}{l}\text { Developmental } \\
\text { Characteristics }\end{array}$ & Filipino Values \\
\hline \multirow{12}{*}{ Grade 7} & $\begin{array}{l}\text { Interacts with others in areas concerning } \\
\text { civics. }\end{array}$ & \multirow{12}{*}{$\begin{array}{l}\text { Discusses thoughts to } \\
\text { people of different } \\
\text { backgrounds } \\
\text { Joins school activities } \\
\text { which may be related to } \\
\text { community and national } \\
\text { concerns } \\
\text { Cooperates in group } \\
\text { activities } \\
\text { Has an increasing } \\
\text { preference for social } \\
\text { networking sites }\end{array}$} & \multirow{12}{*}{$\begin{array}{l}\text { Pagka-makabayan (Demonstrates } \\
\text { nationalism) } \\
\text { Pagka-sensitibo (Sensitive) } \\
\text { Pakikibahagi (Shares one's } \\
\text { thoughts) } \\
\text { Paglawak ng relasyon (Broadening } \\
\text { relationships) }\end{array}$} \\
\hline & Craves for attention from his or her teachers & & \\
\hline & Joins school activities & & \\
\hline & Befriends classmates of both genders & & \\
\hline & Cooperates in group activities & & \\
\hline & $\begin{array}{l}\text { Participates in the exchange of thoughts of } \\
\text { national concern }\end{array}$ & & \\
\hline & Cooperates with others in completing tasks & & \\
\hline & $\begin{array}{l}\text { Understands the needs of his or her } \\
\text { classmates }\end{array}$ & & \\
\hline & Understands individual differences & & \\
\hline & $\begin{array}{l}\text { Help group mates in doing cleaning chores } \\
\text { in classroom. }\end{array}$ & & \\
\hline & Is fond of Facebook/Social media. & & \\
\hline & $\begin{array}{l}\text { Tends to blend in with peers such as in } \\
\text { wearing the same brand of clothes }\end{array}$ & & \\
\hline \multirow{10}{*}{ Grade 8} & $\begin{array}{l}\text { Is capable of relating with others for } \\
\text { example seeks to produce outputs of high } \\
\text { quality }\end{array}$ & \multirow{10}{*}{$\begin{array}{l}\text { Cooperates in } \\
\text { school-related tasks and } \\
\text { understands individual } \\
\text { differences } \\
\text { Joins and identifies with } \\
\text { organizations that promote } \\
\text { their interests } \\
\text { Prefers study groups }\end{array}$} & \multirow[t]{10}{*}{$\begin{array}{l}\text { Pakikiisa (Cooperates with others) } \\
\text { Pakikibahagi (Shares one's } \\
\text { thoughts) }\end{array}$} \\
\hline & Interact and socialize with their peers. & & \\
\hline & $\begin{array}{l}\text { Join several organizations where they feel } \\
\text { accepted and belonged to the group. }\end{array}$ & & \\
\hline & Group collaboration. & & \\
\hline & Building relationships. & & \\
\hline & Cooperation. & & \\
\hline & Participate. & & \\
\hline & Prefers study groups and group works. & & \\
\hline & Interactive in discussion. & & \\
\hline & Sportsmanship in games. & & \\
\hline \multirow{10}{*}{ Grade 9} & Can adjust to the differences of peers & \multirow{10}{*}{$\begin{array}{l}\text { Understands individual } \\
\text { differences } \\
\text { Participates in school } \\
\text { activities } \\
\text { Is active in community } \\
\text { works } \\
\text { Follows group decisions }\end{array}$} & \multirow{10}{*}{$\begin{array}{l}\text { Pagkamaunawain } \\
\text { (Understanding) } \\
\text { Pakikiisa (Cooperates with others) } \\
\text { Pakikisama (Goes along with others } \\
\text { well) }\end{array}$} \\
\hline & Cheerful & & \\
\hline & Participates in activities given by teachers & & \\
\hline & Helpful & & \\
\hline & Shares knowledge with groupmates & & \\
\hline & $\begin{array}{l}\text { Is able to relate with peers with varying } \\
\text { backgrounds }\end{array}$ & & \\
\hline & $\begin{array}{l}\text { Interacts with people from different } \\
\text { religions }\end{array}$ & & \\
\hline & Active in community works & & \\
\hline & $\begin{array}{l}\text { Know how to share ideas with each other } \\
\text { especially if there are activities to be done }\end{array}$ & & \\
\hline & $\begin{array}{l}\text { Going out with friends after class is } \\
\text { noticeable }\end{array}$ & & \\
\hline \multirow{9}{*}{$\begin{array}{c}\text { Grade } \\
10\end{array}$} & $\begin{array}{l}\text { Gets along with people and relates with } \\
\text { them to finish task early }\end{array}$ & \multirow{9}{*}{$\begin{array}{l}\text { Negotiates with classmates } \\
\text { to get things done } \\
\text { Is knowledgeable of the } \\
\text { importance of following } \\
\text { rules } \\
\text { Participates in the school } \\
\text { and community advocacies } \\
\text { Demonstrates romantic } \\
\text { behaviors towards romantic } \\
\text { partners } \\
\text { Prefers social networking } \\
\text { sites in communicating }\end{array}$} & \multirow{9}{*}{$\begin{array}{l}\text { Pagka-maunawain (Understanding) } \\
\text { Pagka-ma-respeto (Respectful) } \\
\text { Pakikiisa (Goes along with others } \\
\text { well) } \\
\text { Pagpapakita ng pagmamahal } \\
\text { (Demonstrates affectionate } \\
\text { behaviors) }\end{array}$} \\
\hline & Follows school policies & & \\
\hline & Interacts well with classmates & & \\
\hline & Participates in school programs & & \\
\hline & $\begin{array}{l}\text { Communicates using social networking } \\
\text { sites }\end{array}$ & & \\
\hline & Follows trends in clothes, fashion, etc. & & \\
\hline & Enters romantic relationships. & & \\
\hline & $\begin{array}{l}\text { Accomplishes part assigned in group } \\
\text { activities. }\end{array}$ & & \\
\hline & Is able to work independently and silently. & & \\
\hline
\end{tabular}

The characteristics of junior high school students who are approximately between 12 to 16 years old enters a 
developmental stage characterized by identity formation and forming romantic relationships. It is also characterized by a more meaningful social involvement as the learners' begin to participate in activities towards community development. Seventh graders were reported to discuss thought-provoking issues with same age peers of different backgrounds. The Philippines being a country of varied religious beliefs and backgrounds provide more multicultural understanding of differences, and this had been observed among the adolescents. With the Philippines, being dominantly Catholics, there are however, other religions such as Muslim, Buddhism, and being Christians, the religious background affect the ways adolescents examine their beliefs and faith. Cooperation between and among groups was a salient characteristic as teachers observed that the learners preferred group activities than individual tasks. The eight graders on the other hand, transforms from being a part of a group, to actively cooperating with and leading groups not only inside the classroom but in communities as well. Social development in this level is characterized as being more virtual and interest-centered. The learners prefer to be part of groups where their interests are promoted.

Data looking into the ninth grade students focus on participation in school and community activities and a deeper understanding of individual differences. It can also be surmised that as the learners understood how different their backgrounds are, the more they are learning to form their identity that is different from the others. They also have the tendency to compromise and follow group decisions. The senior students or tenth graders on the other hand are capable of negotiating with classmates, understands the importance of following rules, and demonstrates romantic behaviors. Although romantic relationships may be formed before reaching tenth grade, it was reported that entering relationships become more salient in this stage.

When it came to Erikson's psychosocial theory, the learners in this stage are forming their identities based on their interests and peers. Through constant interaction with their peers, promotion of their interests and being active community members, the learners begin to form a sense of self. Control and independence are main issues and encouragement from teachers and parents are crucial in molding the identity. In particular, learners may have various ways of developing the self where they can base their identity on what other people expect or choose to make an identity of their own.

With regard the Filipino values emulating from the findings, a common value seen across the characteristics is being able to get along with others (pakikiisa) and being able to work thorough differences (pakikibahagi, pakikisama and pagkamaunawain).

Context-wise, Filipino learners value their kapwa (fellow others) and the relationships they maintain and how they ensure positive relationships is being socialized early on. During their primary years, learners develop perspective-taking which is integral in ensuring that there would be positive interpersonal relationships with their formed friendships. Perspective-taking is an important aspect in the development of empathy and other socially-related behaviors (Thomas, 2005). Likewise, among Filipino learners, perspective taking seem to be a spring board for behaviors that are described to be nationalistic and family-oriented. The emerging values and social behaviors also emphasize the importance Filipino learners give to others like being respectful and getting along with others.

\section{Conclusion}

The Filipino learners are found to have the universal attributes of learners as regards the social and emotional dimensions. However, there are attributes which are also very distinct as Filipinos since they were nurtured in the social environment dominated by Filipino culture. As the learner grow older, their thinking skills become refined and sophisticated and along with these developments, emotional and social tasks mature. Moreover, their concepts, definitions and abstractions are within the context of their social realities.

Overall, there are Filipino attributes that match the description of western theorists. However, there are social and emotional attributes which are uniquely Filipino. The developmental tasks and values showed a progression from smaller groups to preferences for wider interpersonal relationships. In emotional development, 
there is an evident progression from being able to express one's emotions to understanding how others feel, while in social development, progression is seen from understanding roles to seeing one's place in the society.

Information on the Filipino learners across grade levels provide teachers and others in the field of education with a grounding on what emotions are important to cultivate and why it should be enhanced, likewise, the findings provide information on how perspective-taking is an important social behavior among children and what it does to a person when he or she gets into the more advanced grade levels. Social and emotional development in the developmental levels analyzed serve as platform to complex emotions when the learners grow up. Teachers may make use of the areas as bases of activities that would promote emotional wellness and social adjustment. Research on areas focusing on expounding the emotional and social development per stage should be undertaken to provide information to the growing understanding of Filipino learners. Scales and other measurement tools should likewise be used in approximating developmental advancements/or delays.

\section{References:}

Guthrie, H. A., Guthrie, G. A., \& Tayag, A. (1968). Nutritional status and intellectual performance in a rural Philippine community. Philippine Journal of Psychology, 1(1), 28-34.

Pe-Pua, R., \& Protacio-Marcelino, E. (2000). Sikolohiyang pilipino (Filipino psychology): A legacy of Virgilio G. Enriquez. Asian Journal of Social Psychology, 3(1) 49-71. http://dx.doi.org/10.1111/1467-839x.00054

Sroufe, L. A. (2000). Early relationships and the development of children. Infant Mental Health Journal, 21(1), 67-74. http://dx.doi.org/10.1002/(SICI)1097-0355(200001/04)21:1/2<67::AID-IMHJ8>3.0.CO;2-2

Thomas, R. M. (2005). Comparing theories of child development. Belmont, California: Thomson Wadsworth.

Ventura, E. (1994). The Filipino child as a learner: A review of research and prospects. Philippine Journal of Educational Measurement, 1(1), 16-33. 
Rungduin, T. T., \& Reyes, Z. Q. 